\title{
Metode Bermain Jawaban Untuk Meningkatkan Kemampuan Menulis Siswa Kelas II SDN 06 Kampung Baru Kecamatan Pariaman Timur Kota Pariaman
}

\section{Yeni Suryanti}

\begin{abstract}
Students are rarely highly motivated in Bahasa learning, including answer questions, give response to questions, and do discussion that can improve student's writing skill. This research is aimed to determine whether the use of playing-answer method can improve student's writing skill in Bahasa learning. This is a class action research in which 20 elementary students of grade III as subject. Data were obtained through observation, interview, and test of writing skill. There is improvement in each cycle. In cycle I, average score of student's writing skill is 68 or 55\%. Meanwhile in cycle II, average score of student's writing skill is 77,5 or 80\%. This result shows that playing-answer method can improve student's writing skill in Bahasa learning.
\end{abstract}

Keyword: writing skill, playing-answer method

Copyright (C) 2016 IICET (Padang - Indonesia) - All Rights Reserved Indonesian Institute for Counseling, Education and Theraphy (IICET)

\section{PENDAHULUAN}

Pembelajaran Bahasa Indonesia terdiri atas empat aspek keterampilan yaitu menyimak, berbicara, membaca dan menulis. Salah satu bidang aktivitas dan materi pengajaran bahasa Indonesia di Sekolah Dasar yang memegang peranan penting ialah pengajaran menulis. Untuk menghasilkan tulisan yang baik setiap orang diharuskan memiliki keterampilan menulis. Keterampilan menulis akan tercipta dengan sendirinya apabila diiringi dengan hobi dan latihan yang terus menerus, karena menulis merupakan keterampilan berbahasa yang harus dikuasai dengan baik oleh siswa. Dengan menulis seseorang dapat mengungkapkan perasaan, ide, dan gagasan. Proses menulis adalah kegiatan penulis dalam menghasilkan suatu tulisan. Kegiatan tersebut diawali dengan memilih, memilah dan menyusun tulisan, menuliskan pesan dalam bahasa tulis ,dan menyerpunakan (merevisi) tulisan sebelum disampaikan kepada orang lain (pembaca). Penulis melaksanakan kegiatan tersebut secara bertahap dan berlanjut ulang. Selain penulis mengunakan pengetahuan dan pengalaman (skemata), penulis harus mampu menggunakan unsur retorika berbahasa dan penalaran dalam proses menulis.

Menurut Susanto (2014: 249) menulis adalah kegiatan seseorang menempatkan sesuatu pada sebuah dimensi ruang yang masih kosong, setelah itu hasilnya yang berbentuk tulisan dapat dibaca dan dipahami isinya. Dalam pembelajaran Bahasa Indonesia kemampuan menulis memiliki arti, yaitu: (1) Menulis dalam arti mengekspresikan atau mengemukakan pikiran, perasaan dalam bahasa tulis, (2) Menulis dalam arti melahirkan bunyi-bunyi bahasa, ucapan dalam bentuk tulisan untuk menyampaikan pesan berupa pikiran dan perasaan. Selain itu Susanto (2014: 249) mengatakan menulis suatu kegiatan yang sifatnya berkelanjutan sehingga pembelajarannya dilakukan berkesinambungan sejak di bangku TK. Hal ini didasarkan pada pemikiran bahwa menulis merupakan dasar sebagai bekal belajar menulis di jenjang pendidikan berikutnya. Menulis bukanlah sekedar coretan tinta didalam buku, namun harus mempunyai makna dan informasi yang akan disampaikan. Oleh karena itu dalam proses pembelajaran siswa dilatih dalam menulis dengan baik agar orang lain/pembaca bisa memahami. Untuk menyampaikan informasi pada pembaca, tulisan harus disajikan dengan tata bahasa yang mudah dipahami. Selain itu, terdapat metodologi-metodologi tersendiri agar tulisan yang dibuat terstruktur rapi.

Seorang penulis memiliki tujuan-tujuan tersendiri sesuai dengan bentuk-bentuk tulisannya. Namun,di SD pembelajaran menulis memiliki tujuan tersendiri sesuai dengan tingkatan kelas siswa SD yang bersangkutan. Pembelajaran menulis di SD dibedakan menjadi dua, yaitu menulis permulaan dan menulis lanjutan, Resmini (dalam Susanto, (2006: 240-242). Pembelajaran menulis lanjutan disebut juga mengarang, seperti mengarang deskripsi. Dari hasil pengalaman peneliti diketahui bahwa hasil belajar mengarang siswa pada masih rendah. Dari 20 siswa di kelas terdapat 12 orang siswa laki-laki dan 8 orang siswa perempuan, siswa yang mendapat nilai di atas 70 sebanyak 12 orang dan nilai di bawah 70 sebanyak 8 orang. Sedangkan 
Kriteria Ketuntasan Minimal (KKM) adalah 70. Hal ini membuktikan bahwa kurangnya kemampuan siswa dalam menulis suatu karangan yang ditandai dengan rendahnya nilai karangan siswa. Dalam meningkatkan kemampuan, peneliti mencoba melaksanakan metode bermain jawaban, dalam bermain jawab ini siswa diperlukan latihan dan kebiasaan menulis yang sesuai dengan pembelajaran. Keterampilan menulis dapat membantu kita menyerap dan menguasai informasi serta menghasilkan ide-ide baru yang dapat digunakan sebagai sumber belajar. Dengan mengetahui dan mengikuti langkah-langkah yang jelas siswa diharapkan menghasilkan penulisan yang baik dan benar.

Untuk meningkatkan kemampuan menulis siswa, guru dapat menggunakan berbagai strategi, pendekatan, model, ataupun model. Salah satu yang dianggap tepat oleh peneliti untuk meningkatkan kemampuan menulis siswa adalah dengan menggunakan metode bermain jawaban. Menurut Zaini, dkk (2005: 87-88) metode bermain jawaban adalah sebuah permainan yang dapat melibatkan semua siswa dari menitmenit awal sampai akhir. Dalam permaianan ini, siswa ditantang untuk mencari jawaban yang benar dan sekaligus bergantung pada faktor keberuntungan. Permainan ini dapat digunakan untuk pretest maupun posttest, disamping tentunya untuk mengajarkan materi yang baru. Dalam permainan ini, guru mengajar dengan menggunakan jawaban-jawaban yang ditemukan oleh siswa.

Berpijak dari latar belakang di atas, maka peneliti melakukan penelitian tindakan kelas yang mengimplementasikan metode bermain jawaban dalam pembelajaran Bahasa Indonesia. Dengan perlakuan ini, diharapkan dapat meningkatkan kemampuan menulis siswa dalam pembelajaran Bahasa Indonesia. Penelitian ini bertujuan untuk menjelaskan: (1) mendeskripsikan pengaruh implementasi metode bermain jawaban dalam pembelajaran terhadap proses pembelajaran Bahasa Indonesia siswa dan (b) mengetahui pengaruh implementasi metode bermain jawaban dalam pembelajaran kemampuan menulis siswa.

\section{METODOLOGI PENELITIAN}

Penelitian tindakan kelas ini dilakukan di SD Negeri 06 Kampung Baru, Kecamatan Pariaman Timur, Kota Pariaman, dengan mempertimbangkan bahwa sekolah tersebut mau menerima inovasi pendidikan terutama dalam proses pembelajaran untuk peningkatan motivasi siswa pada pembelajaran Bahasa Indonesia. Subjek dalam penelitian ini adalah siswa kelas II di SD Negeri 06 Kampung Baru, Kecamatan Pariaman Timur, Kota Pariaman yang berjumlah 20 orang, yang terdiri dari 12 laki-laki dan 8 perempuan. Jenis penelitian ini adalah penelitian tindakan kelas yang meliputi tahap perencanaan, pelaksanaan, pengamatan, dan refleksi. Data penelitian ini dikumpulkan dengan menggunakan pencatatan lapangan, observasi, wawancara dan hasil tes. Indikator keberhasilan hasil belajar siswa di katakan tuntas apabila mendapatkan nilai 70 atau lebih, sesuai dengan standar KKM. Data yang diperoleh kemudian dianalisis dengan menggunakan pendekatan kualitatif dan kuatitatif karena peneliti ingin mengamati fenomena yang terjadi di dalam kelas.

\section{HASIL DAN PEMBAHASAN PENELITIAN}

\section{A. Hasil Penelitian \\ 1. Siklus I \\ a) Tahap Perencanaan}

Sebelum menerapkan tindakan pada siklus I, terlebih dahulu peneliti menyiapkan rencana pelaksanaan pelajaran (RPP), lembar observasi kemampuan menulis siswa, lembar observasi kegiatan guru, soal latihan dan lembar jawaban yang sesuai dengan model yang peneliti laksanakan.

b) Tahap Pelaksanaan

Pelaksanaan pembelajaran pada siklus I, dengan menggunakan model bermain jawaban dikelas II SD Negeri 06 Kampung Baru, Kecamatan Pariaman Timur, Kota Pariaman. Pembelajaran ini dilaksanakan 2 x pertemuan.

c) Tahap Pengamatan

Pengamatan dilaksanakan pada waktu proses pembelajaran dengan menggunakan model bermain jawaban. Berikut adalah Tabel 1 yang menyajikan hasil belajar berupa kemampuan menulis siswa pada siklus I. 
Tabel 1

Ketuntasan Dan Rata-Rata Hasil Belajar Kemampuan Menulis Siswa Dalam Pembelajaran Bahasa Indonesia Dengan Metode Bermain Jawaban Pada Siklus I

\begin{tabular}{lcc}
\hline \multicolumn{1}{c}{ Uraian } & Nilai & Target \\
\hline Jumlah siswa yang mengikuti tes & 20 & - \\
\hline Jumlah siswa yang tuntas & 11 & - \\
Jumlah siswa yang tidak tuntas & 9 & - \\
Persentase ketuntasan belajar siswa & $55,00 \%$ & $70 \%$ \\
Rata-rata skor siswa & 68 & 70 \\
\hline
\end{tabular}

Dari Tabel 1 di atas dapat dilihat bahwa hasil belajar kemampuan menulis siswa pada tes akhir siklus I siswa yang mengikuti tes hasil belajar adalah 20 orang. Sedangkan siswa yang tuntas dalam tes adalah 11 orang dan yang tidak tuntas adalah 9 orang. Persentase ketuntasan hasil belajar adalah 55,00\%, sedangkan target ketuntasan hasil belajar adalah 70\%. Dari hasil diskusi peneliti dengan kolabolator perlu dilanjutkan ke siklus II yang akan direncanakan dan dilaksanakan dengan lebih baik.

\section{d) Tahap Refleksi}

Kegiatan refleksi dilakukan antara peneliti dengan kepala sekolah yang dilakukan pada setiap siklus berakhir. Refleksi siklus I ini mencakup refleksi terhadap perencanaan, pelaksanaan, kegiatan, dan hasil yang diperoleh oleh siswa. Dari tahap perencanaan, peneliti mempersiapkan RPP, lembar observasi kegiatan menulis siswa, observasi guru, tes hasil belajar. Dalam tahap ini, peneliti belum mempersiapkan perencanaan dengan maksimal. Berdasarkan temuan di atas, peneliti mengidentifikasi beberapa penyebab terjadinya masalah tersebut adalah karena baik guru maupun siswa kurang memahami metode bermain jawaban.

Permasalahan ini berdampak pada kurang maksimalnya hasil belajar dan peneliti memutuskan untuk melanjutkan penelitian pada siklus II. Adapun yang dapat dilakukan guru untuk meningkatkan kemampuan belajar siswa pada siklus II adalah: (1) guru harus lebih memahami metode bermain jawaban dan (2) guru harus meningkatkan kreatifitas siswa, agar siswa aktif dalam proses pembelajaran.

\section{Siklus II}

a) Tahap Perencanaan

Hasil analisis refleksi pada siklus I menunjukkan keberhasilan penelitian belum mencapai tujuan yang diharapkan. Berdasarkan hasil tindakan dari siklus I yang telah diuraikan di atas maka pada siklus II ini perencanaan tindakan yang akan dilaksanakan meliputi penyiapan rencana pelaksanaan pelajaran (RPP), lembar observasi kegiatan menulis siswa, lembar observasi kegiatan guru dan soal latihan menulis..

\section{b) Tahap Pelaksanaan}

Sama dengan pelaksanaan siklus I, proses pelaksanaan siklus II terbagi menjadi dua kali pertemuan. Pertemuan pertama berlangsung selama 2x35 menit dan pertemuan kedua berlangsung selama $3 \times 35$ menit.

c) Tahap Pengamatan

Berdasarkan hasil tes siklus II, persentase siswa yang tuntas tes akhir siklus dan rata-rata skor tesnya dapat dilihat pada Tabel 2 berikut.

Tabel 2

Ketuntasan Dan Rata-Rata Hasil Belajar Kemampuan Menulis Siswa Dalam Pembelajaran Bahasa Indonesia Dengan Metode Bermain Jawaban Pada Siklus II

\begin{tabular}{lcc}
\hline \multicolumn{1}{c}{ Uraian } & Nilai & Target \\
\hline Jumlah siswa yang mengikuti tes & 20 & - \\
Jumlah siswa yang tuntas & 16 & - \\
Jumlah siswa yang tidak tuntas & 4 & - \\
Persentase ketuntasan belajar siswa & $80,00 \%$ & $70 \%$ \\
Rata-rata skor siswa & 77,5 & 70 \\
\hline
\end{tabular}

Berdasarkan Tabel 2 di atas dapat dilihat bahwa hasil belajar menulis siswa pada tes akhir siklus II, siswa yang mengikuti tes hasil belajar adalah 20 orang. Sedangkan siswa yang tuntas dalam tes adalah 16 orang dan yang tidak tuntas adalah 4 orang. Persentase ketuntasan hasil belajar adalah 80,00\%, sedangkan target ketuntasan hasil belajar adalah $70 \%$ 


\section{d) Tahap Refleksi}

Kegiatan refleksi dilakukan secara kolaboratif dengan kepala sekolah (observer) pada setiap pembelajaran berakhir. Pada kesempatan ini temuan dan hasil pengamatan peneliti dibahas bersama. Refleksi tindakan siklus II ini mencakup refleksi terhadap perencanaan, pelaksanaan, pengamatan, catatan lapangan dan hasil yang diperoleh oleh siswa. Dilihat dari data hasil tes siklus II siswa, maka sudah mencapai target yang ditetapkan dan keberhasilan belajar sangat baik mengunakan metode bermain jawaban. Sedangkan data pengamatan kegiatan guru dalam mengelola pelajaran sudah mengalami peningkatan dibandingkan pada siklus I, dan dapat dikatakan cukup baik. Berdasarkan analisis data yang telah diuraikan di atas, maka disimpulkan bahwa peningkatan kemampuan menulis melalui metode bermain jawaban dalam pembelajaran bahasa Indonesia kelas II SD N 06 Kampung Baru Kota Pariaman sudah meningkat, dan karena itu diputuskan untuk tidak melanjutkan penelitian pada siklus berikutnya. Dengan demikian penelitian ini telah selesai.

\section{B. Pembahasan}

Penelitian tindakan kelas ini terdiri dari dua siklus yang setiap siklusnya terdiri dari 2 kali pertemuan dan 1 kali tes hasil belajar pada akhir siklus. Pelaksanaan pembelajaran yang dilaksanakan menggunakan metode pembelajaran bermain jawaban. Penelitian ini menggunakan instrumen penelitian berupa lembar observasi kegiatan menulis belajar siswa, lembar observasi kegiatan guru, serta tes hasil belajar menulis siswa. Melalui metode pembelajaran bermaian jawaban merupakan hal yang baru bagi siswa sehingga dalam pelaksanaannya peneliti menemui berbagai kendala.

Berdasarkan gambaran serta penjelasan tentang metode pembelajaran bermain jawaban di atas, peneliti memulai penelitian dengan merancang beberapa tahapan, dimulai perencanaan yaitu mengkaji silabus mata pelajaran Bahasa Indonesia kelas II semester genap, kemudian peneliti menyiapkan perangkat pembelajaran (RPP). Selanjutnya, peneliti memilih buku pegangan yaitu buku paket Bahasa Indonesia penerbit Erlangga untuk SD kelas II. Lalu, peneliti menyiapkan media pembelajaran, menyusun lembar observasi kegiatan menulis siswa, menyusun lembar observasi kegiatan guru, dan menyusun tes hasil belajar menulis siswa. Selanjutnya, pada proses pelaksanaan pembelajaran yang dimulai dari kegiatan awal berisi berdo'a, apersepsi dan kegiatan menulis, kegiatan inti berisi menyampaikan materi pelajaran, pembelajaran menggunakan metode pembelajaran bermain jawaban dan cara guru dalam melaksanakan proses pembelajaran yaitu eksplorasi, elaborasi, dan konfirmasi. Kemudian, pada kegiatan akhir pembelajaran, berisi evaluasi dan untuk memperkuat data kejelasan peningkatan tersebut maka diadakan tes hasil belajar yang di sini peneliti gunakan adalah berupa soal tes menulis.

Berdasarkan hasil ulangan siswa yang dilakukan pada setiap akhir siklus, hasil belajar menulis mengalami peningkatan yang cukup baik. Peningkatan ini terlihat dari nilai rata-rata kelas yang meningkat pada setiap siklusnya. Peningkatan tersebut dapat dilihat pada Tabel 3 berikut ini.

Tabel 3

Perbandingan Persentase Hasil Belajar Kemampuan Menulis Siswa Dalam Pembelajaran Bahasa Indonesia Dengan Metode Bermain Jawaban Pada Siklus I dan Siklus II

\begin{tabular}{ccc}
\hline Perbandingan Hasil Belajar Menulis Siswa & Peningkatan \\
\hline Siklus I & Siklus II & \\
$55 \%$ & $80 \%$ & $25 \%$ \\
\hline
\end{tabular}

Berdasarkan tabel di atas dapat dilihat bahwa terjadi peningkatan sebesar $25 \%$ pada persentase ketuntasan tes hasil belajar siswa, yakni dari 55\% pada siklus I meningkat menjadi $80 \%$ pada siklus II.

\section{KESIMPULAN DAN SARAN \\ KESIMPULAN}

Berdasarkan hasil penelitian dan pembahasan yang telah dipaparkan sebelumnya, maka peneliti menyimpulkan hal-hal sebagai berikut.

1. Siswa yang menulis dengan tepat berdasarkan gambar pada siklus 1 dengan persentase 32,05\%, sedangkan pada siklus II siswa yang menulis dengan tepat berdasarkan gambar dengan persentase $72,05 \%$. Sehingga dalam kategori baik.

2. Siswa yang menulis berdasarkan penggunaan huruf kapital pada siklus 1 dengan persentase $40,00 \%$, sedangkan pada siklus II siswa yang menulis berdasarkan penggunaan huruf kapital berjumlah dengan persentase $82,05 \%$. Sehingga dalam kategori baik. 
3. Terjadinya peningkatan hasil belajar kemampuan menulis siswa siklus I dengan rata-rata 68 dan ratarata siklus II 77,5. Sedangkan persentase siklus I 55\% dan persentase siklus II 80\% sehingga dapat dikatakan bahwa penelitian tindakan ini berhasil.

\section{SARAN}

Sehubungan dengan hasil penelitian yang diperoleh, maka peneliti memberikan saran dalam pelaksanaan pembelajaran dengan model bermain jawaban sebagai berikut:

1. Bagi siswa, agar meningkat kemampuan menulis siswa dalam proses pembelajaran dengan berpartisipasi menjawab pertanyaan, menanggapi pertanyaan dan berdiskusi karena dengan siswa aktif dalam berdiskusi maka akan menunjang semangat belajar.

2. Bagi guru yang melaksanakan pembelajaran dengan model bermain jawaban dapat memberikan kesempatan bagi siswa dalam proses pembelajaran yaitu mengajukan pertanyaan, menjawab pertanyaan dan menyimpulkan pelajaran dan dijadikan salah satu alternatif variasi dalam pelaksanaan pembelajaran sehingga bisa meningkatkan kemampuan menulis siswa.

3. Bagi peneliti yang mengambil judul ini sebaiknya dalam pembelajaran divariasikan dengan media gambar sehingga siswa tidak monoton atau jenuh dalam pembelajaran.

\section{DAFTAR PUSTAKA}

2007. Kurikulum Tingkat Satuan Pendidikan Sekolah Dasar. Jakarta: BSNP

Arikunto, Suharsimi. 2006. Penelitian Tindakan Kelas. Jakarta: Bumi Aksara

Asy’ari, Maslichah. 2006. Penerapan Pendekatan Sains Teknologi Masyarakat Dalam Pembelajaran Sains

Di SD. Yogyakarta: Universitas Sanata Dharma

Diyanto, 2006. Penerapan Model Pembelajaran Cooperative Learning Melalui Tipe Bermain Jawaban dalam Upaya Meningkatkan Hasil Belajar Siswa Kelas IV SDN 20 Kumango, Kabupaten Tanah Datar. Padang: UNP

Hamalik, Oemar. 2007. Proses Belajar Mengajar. Jakarta: Bumi Aksara

Mulyasa, E. 2006. Kurikulum Yang Disempurnakan. Bandung: Remaja Rosdakarya

Pebriyenni. 2009. Pembelajaran IPS II (Kelas Tinggi). Padang: Dikti- Depdiknas dan Jurusan PGSD FKIP Bung Hatta

Sanjaya, Wina. 2008. Kurikulum Pembelajaran. Jakarta: Prenada Media Grup

Suprijono, Agus 2013. Cooperative Learning. Yogyakarta: Pustaka Belajar

Trianto. 2012. Model Pembelajaran Terpadu. Jakarta: Bumi Aksara

Tukiran, Taniredja. 2010. Penelitian Tindakan Kelas. Bandung: Alfabeta

Warsono dan Hariyanto. 2013. Pembelajaran Aktif. Bandung: Remaja Rosdakarya Offset 